\title{
A SIMPLE METHOD FOR THE CONTINUOUS ELECTRO- PHORESIS OF SERUM PROTEINS
}

\author{
BY \\ MARGARET H. HOBART AND CHARLES F. M. ROSE \\ From the S. A. Courtauld Institute of Biochemistry, Middlesex Hospital Medical School, London
}

(RECEIVED FOR PUBLICATION APRIL 12, 1955)

In 1951 Durrum introduced a simple apparatus for the continuous separation of amino-acids, proteins, and other charged substances. Since then various modifications have been made based on the original Durrum idea to use a sheet of filter paper as the supporting medium. Most of these modifications have tended to make the construction and working of the apparatus much more difficult and therefore it was decided to attempt to construct the simplest possible apparatus for the separation of serum proteins. It was found that using the Durrum apparatus with a very few modifications the separation of serum proteins could be continuous for a period of one week.

\section{The Apparatus}

The apparatus is constructed as shown in Fig. 1 from $\frac{1}{4}$ in. perspex, and consists of a box 20 in. high, 14 in. wide, and 5 in. deep, with a detachable twopanelled front, the bottom panel 6 in. high and the top panel 14 in. high, having an upper buffer trough from which the paper curtain hangs and two lower subdivided electrode compartments into which the sides of the paper dip. The veronal buffer is continuously fed into the trough from a higher reservoir at a rate of 15 drops per minute and the excess flows by means of a constant levelling device into a small reservoir of approximate volume $20 \mathrm{ml}$., which, when full, flushes into the front lower buffer tanks. These tanks are subdivided so that the front compartment into which the paper dips is connected via two small holes to the back compartment into which the electrode vessel enters.

The electrode and lower buffer tank are shown in Fig. 2.

The most satisfactory paper so far used is Whatman No. $3 \mathrm{MM}$, cut with the machine direction of flow towards the anode; the dimensions of the curtain are shown in Fig. 3. The filter paper is folded so that $3.5 \mathrm{~cm}$. of the paper folds back into the buffer trough and the rest of the paper hangs vertically as a curtain with 14 collection points at its base and the two outside tabs dripping into the two front buffer tanks. To increase the downward flow of buffer on either side of the paper one extra piece of paper is placed in each top corner, while three extra pieces are placed in the two bottom corners to increase the current flow across the base of the paper. A small tab, $1 \mathrm{~mm}$. wide, is cut in the position shown and bent forward. A wick of the same paper $1 \mathrm{~mm}$. wide connects this tab with serum in a watch glass at a higher level. Phenol red is added to the serum to serve as an indicator, which, when the apparatus is running correctly, migrates ahead of the albumin fraction. Before the wick and tab are connected the paper is allowed to reach saturation and a constant current flow.

A stable current is supplied to give $17 \mathrm{~mA}$ and 500 volts. The electrodes are prepared from $2 \mathrm{~mm} 8$ silver wire bent into the required coil to fit the electrode vessels and coated with silver chloride. For convenience, the silver before it is coated is pushed through a polythene stopper which fits loosely into the glass electrode vessel. The electrode is immersed in a solution of saturated potassium chloride and is separated from the buffer tank by means of an agar bridge. This electrode system has proved very satisfactory in operation, as it eliminates any possible $p \mathrm{H}$ changes reaching the paper curtain and keeps the current steady throughout the separation.

This apparatus has been in constant use for the past 18 months and has proved very satisfactory for the separation of approximately $7 \mathrm{ml}$. of serum into its component fractions over a period of one week, provided that the silver electrodes are changed over every 24 hours.

When the required amount of serum has been separated the paper curtain is removed and dried horizontally at a temperature sufficient to denature the residual proteins; the paper is then stained by any of the usual protein staining techniques. From the stained pattern on the paper it is very simple to identify the protein fractions which have been collected into the various tubes, and we have found a remarkable consistency in the position of the protein fractions of various separations.

\section{Reagents}

Barbitone Buffer, pH 8.6. - Sodium diethylbarbiturate, 7.75 g., and 1.38 g. of diethylbarbituric acid are diluted to 1 litre with distilled water. 


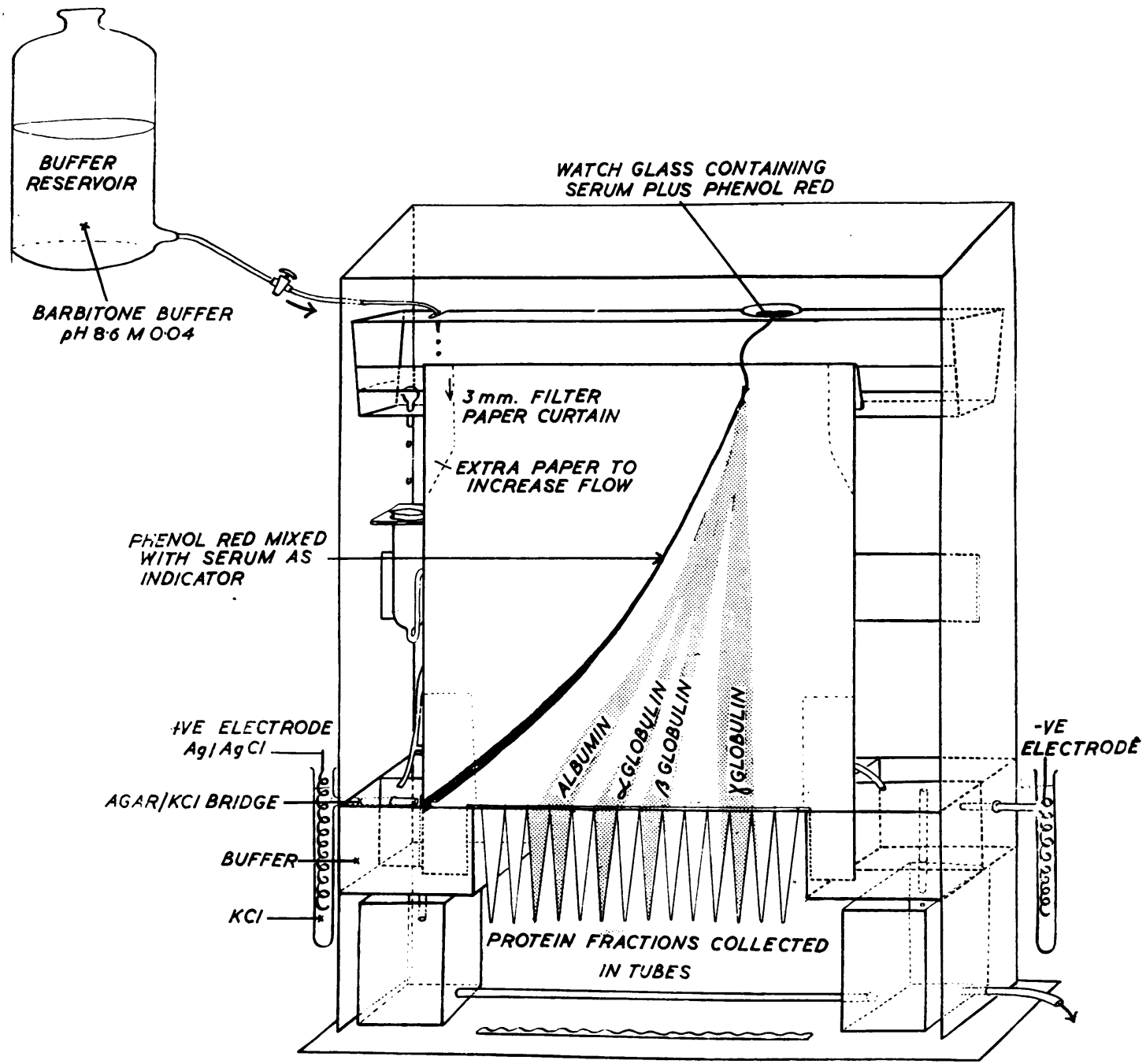

FIG. 1.-Diagram of apparatus. 
Fig. 2.-Diagram of electrode and lower buffer tank.

FIG. 3.-Diagram of paper curtain.

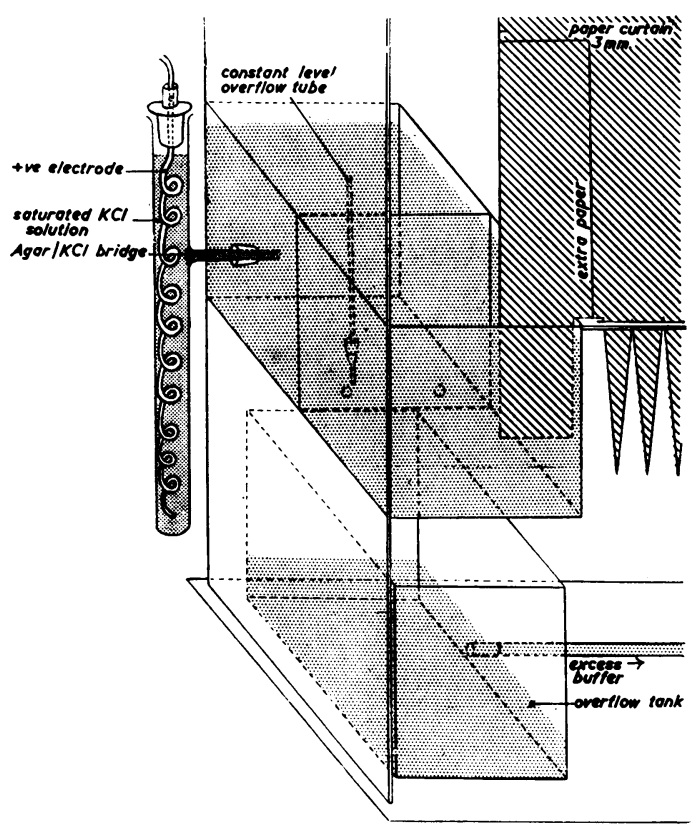

FIG. 2

Agar--Agar, 2 g., is diluted to $100 \mathrm{ml}$. with a saturated solution of potassium chloride.

\section{Preparation of the Silver/Silver Chloride Electrodes}

One foot of $2 \mathrm{~mm}$. silver wire is coiled into the required shape (to fit the electrode vessel) and first cleaned for a few seconds only in concentrated nitric

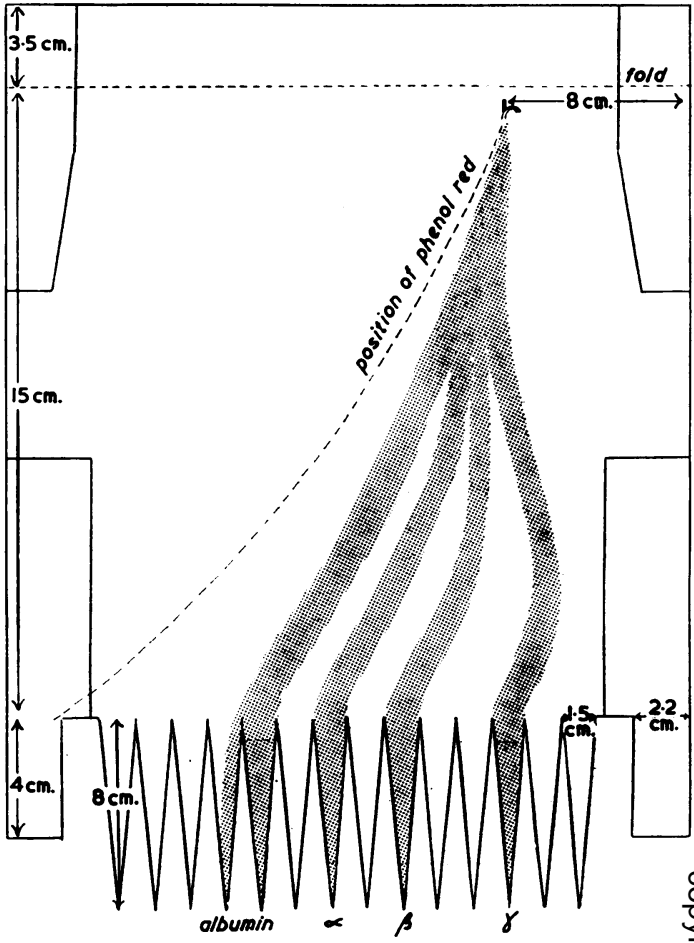

FIG. 3

acid and washed with distilled water. The silver wire is then placed as the anode in an electrolytic cell with a platinum cathode in $6 \%$ hydrochloric acid and a current of $20 \mathrm{~mA}$ is passed for $\mathbf{4 8}$ hours.

We wish to thank Professor Sir Charles Dodds for his interest in this work.

\section{REFERENCE}

Durrum, E. L. (1951). J. Amer. chem. Soc., 73, No. 10, p. 4878. 